\title{
PENGARUH KOMPENSASI DAN KESELAMATAN KESEHATAN KERJA TERHADAP KOMITMEN ORGANISASIONAL TENAGA KERJA DINAS LINGKUNGAN HIDUP TABANAN
}

\author{
Dewa Ayu Diah Kumala Dewi ${ }^{1}$ \\ Putu Saroyini Piartrini ${ }^{2}$ \\ ${ }^{1,2}$ Fakultas Ekonomi dan Bisnis Universitas Udayana (Unud), Bali, Indonesia \\ email: diahkumala97@yahoo.com
}

\begin{abstract}
ABSTRAK
Sumber Daya Manusia (SDM) yang baik akan membantu menyesaikan tugas-tugas dari organisasinya, selain itu loyalitas juga sangat penting guna membangun komitmen didalam suatu organisasi. Tujuan penelitian ini untuk mengetahui pengaruh kompensasi, keselamatan dan kesehatan kerja terhadap komitmen organisasional. Penelitian ini dilakukan pada Dinas Lingkungan Hidup Kabupaten Tabanan. Jumlah sampel yang digunakan yaitu 159 tenaga kerja, dengan metode random sampling. Pengumpulan data dilakukan dengan metode kuesioner dan wawancara secara langsung. Teknik analisis yang digunakan dalam penelitian ini yaitu analisis regresi linear berganda. Dalam penelitian ini ditemukan hasil bahwa kompensasi dan keselamatan dan kesehatan kerja berpengaruh positif terhadap komitmen organisasional tenaga kerja Dinas Lingkungan Hidup Kabupaten Tabanan. Bagi organisasi diharapkan lebih memperhatikan lagi cara pemberian kompensasi dengan menyesuaikan UU yang berlaku dan ditingkatkan padabagian K3.
\end{abstract}

Kata kunci : Kompensasi, Keselamatan dan Kesehatan Kerja, Komitmen Organisasional

\begin{abstract}
A good Human Resources (HR) will help settle the tasks of the organization, besides loyalty is also very important to build commitment in an organization. The purpose of this study was to determine the effect of compensation, work safety and health on organizational commitment. This research was conducted at the Dinas Lingkungan Hidup Kabupaten Tabanan. The number of samples used was 159 workers, with a random sampling method. Data collected using questionnaire and direct interview. The analysis technique used in this study is multiple linear regression analysis. In this study, it was found that compensation and work safety and health had a positive effect on the organizational commitment. Organizations are expected to pay more attention to how to provide compensation by adjusting applicable laws and improving the work safety and health.
\end{abstract}

Keywords: Compensation, work safety and health, Organizational Commitment 


\section{PENDAHULUAN}

Sumber Daya Manusia (SDM) merupakan elemen yang berpengaruh didalam perkembangan organisasi, sehingga memiliki sumber daya manusia yang berkualitas penting dalam mencapai keberhasilan dari organisasi, adanya rasa loyalitas juga tidak kalah penting guna menciptakan komitmen didalam organisasi. Sumber daya manusia yang dimaksud disini adalah tenaga kerja yang dapat membantu mensukseskan tugas-tugas dari organisasi salah satunya tugas dari Dinas Lingkungan Hidup Kabupaten Tabanan. Tugas dari Dinas Lingkungan Hidup Kabupaten Tabanan yakni menjaga kebersihan lingkungan di wilayah Kabupaten Tabanan.

Komitmen organisasional merupakan keadaan yang menunjukan kararteristik hubungan antara pekerja dengan sebuah organisasi sehingga mempengaruhi setiap keputusan yang diambil oleh karyawan (Setiawan \& Piartrini, 2018). Individu dengan komiten yang tinggi akanberusahan semaksimal mungkin untuk dapat menyelesaikan tugas dari organisasi. Terdapat tiga dimensi yaitu komitmen afektif, komitmen berkelanjutan dan komitmen normatif. Komitmen efektif merupakan keinginan dari diri sendiri untuk tetap berada pada suatu organisasi, komitmen berkelanjutan merupakan komitmen yang timbul karena didasari oleh pertimbangan untung atau rugi dan komitmen normatif perasaan wajib untuk tetap bekerja dalam organisasi (Kerisna \& Suana, 2017).

Dinas Lingkungan Hidup (DLH) Kabupaten Tabanan memiliki 3 bidang yaitu Bidang penataan dan penaatan perlindungan pengelolaan lingkungan hidup, Bidang pengelolaan sampah, limbah bahan berbahaya dan beracun dan peningkatan kapasitas dan Bidang pengendalian pencemaran dan kerusakan lingkungan hidup. Bidang pengelolaan sampah, limbah bahan berbahaya dan beracun dan peningkatan kapasitas memiliki tiga sub bidang yakni bagian pertanaman, bagian air limbah dan bagian pengangkutan yang didalamnya termasuk tenaga kerja yang dibagi lagi menjadi 12 kelompok kerja diantaranya mandor, supir hunter kebersihan, tenaga motor gerobak sampah, tenaga cikar barat, tenaga cikar timur, tenaga sapu pasar di kecamatan, tenaga sapu pasar senggol gajah mada, tenaga sapu pasar kediri, tenaga sapu pasar tabanan, tenaga sapu pasar dauh pala, tenaga sapu timur dan tenaga sapu barat.

Tugas pokok dan fungsi dari masing-masing kelompok diantaranya ada mandor yang bertugas mengawasi pekerja di lapangan, mengecek sarana dan prasarana yang akan digunakan oleh tenaga kerja serta mengabsen jumlah tenaga kerja. Supir hunter kebersihan bertugas mengangkut sampah disetiap titik yang sudah dikumpulkan terlebih dahulu ditong sampah kontainer kemudian langsung dibawa ke TPA di daerah kerambitan di desa mandung. Tenaga motor gerobak dan tenaga cikar yang bertugas mengambil sampah-sampah dirumah warga dengan transportasi yang mereka miliki. Tenaga sapu bertugas membersihkan lingkungan di masing-masing wilayah yang sudah di tentukan sebelumnya.

Hasil wawancara awal yang dilakukan kepada 5 orang tenaga kerja di Dinas Lingkungan Hidup Kabupaten Tabanan, putu, nyoman, komang, made dan wayan. Putu (nama asli disamarkan) dari tenaga tukang sapu mengungkapkan "saya sudah bekerja di sini sekitar 7 tahun dan saya senang bekerja disini karena sudah terbiasa". Berdasarkan ungkapan di atas tenaga kerja memiliki komitmen yang 
timbul dari diri sendiri karena merasa senang dengan pekerjaan yang dilakukannya sampai sejauh ini, hal ini sama dengan halnya komitmen yang bersifat efektif. Dilain kesempatan hasil wawancara 3 dari 10 orang kenaga kerja juga mengungkapkan hal yang sama bahwa mereka merasa senang bekerja di tempat ini karena rekan kerja yang baik dan enak diajak untuk bekerja sama.

Nyoman (nama asli disamarkan) dari tenaga cikar menceritakan pengalamannya "jika saya ditawarankan gaji yang lebih dari disini saya akan keluar dari pekerjaan ini karena gaji disini menurut saya masih kurang". Jika di lihat dari pernyataan diatas tenaga kerja belum tentu akan komitmen dengan organisasinya dilihat dari komitmen berkelanjutan tenaga kerja masih mempertimbangkan untung rugi dari pekerjaannya. Berdasarkan dengan pekerjaan yang dilaksanakan, para tenaga kerja mendapatkan upah yang diterima mulai dari mandor Rp. 34.000 perharinya, supir hunter Rp. 32.000 perharinya, tenaga gerobak Rp. 30.000 perharinya, tenaga cikar Rp. 30.000 perharinya dan tenaga sapu Rp. 29.000 setiap harinya dengan waktu kerja 4 jam dalam 1 harinya dan juga di berlakukan 2 sift yaitu sift pagi yang di mulai dari jam 07.00-11.00 dan sift siang di mulai dari 13.00-16.00.

Komang (nama asli disamarkan) dari tenaga cikar bercerita "saya sudah 10 tahun bekerja disini karna tidak ada pengangkatan dari pusat dan tidak punya keterampilan atau pilihan yang lain makanya saya tetap bekerja disini". Berdasarkan apa yang diceritakan oleh komang hal ini berhubungan dengan komitmen berkelanjutan dimana tenaga kerja mempertimbangkan untung rugi jika meninggalkan organisasi ini. Pilihan lain yang dimaksud disini jika dilihat dari segi umur kebanyakan yang sudah tidak muda lagi selain itu dilihat dari tingkat pendidikan yang masih rendah.

Made (nama asli disamarkan) dari tenaga sapu mengungkapkan "saya merasa kurang senang bekerja di tempat ini karena tidak ada jaminan asuransi kesehatan". Pada dasar dan pelaksanaan keselamatan dan kesehatan kerja berlandaskan UU N0. 13 Tahun 2003 bab x paragraf 5 keselamatan kesehatan kerja (pasal 86 ayat 1) yang menyatakan setiap pekerja/buruh mempunyai hak untuk memperoleh perlindungan atas keselamatan dan kesehatan kerja, moral dan kesusilaan dan perlakuan yang sesuai dengan harkat dan martabat manusia serta nilai-nilai agama. Dilain kesempatan hasil wawancara dengaan tenaga kerja yang lainnya penulis mendapatkan fakta yang sama bahwa tidak adanya jaminan asusansi kesehatan yang diberikan organisasi kepada tenaga kerja, padahal ini merupakan sesuatu yang sangat penting bagi pekerja mengingat tenaga kerja melakukan kontak langsung dengan sampah atau kotoran yang lainnya, tidak menutup kemungkinan tenaga kerja akan terkontaminasi dan menyebabkan resiko penyakit-penyakit berbahaya yang disebabkan oleh sampah.

Wayan (nama asli disamarkan) dari tenaga sapu menjelaskan "perlengkapan kerja yang di berikan oleh organisasi sudah sesuai dengan apa yang dibutuhkan saat bekerja". Berdasarkan penjelasan dari tenaga kerja pada saat ini organisasi sudah memenuhi kebutuhan pekerja seperti alat-alat dan pakaian lengkap, topi, masker, slop tangan dan sepatu boot di tambah juga dengan sapu lidi, keranjang dan sodo plat yang akan digunakan pekerja di dalam melaksanakan pekerjaan. Peralatan tersebut dibutuhkan oleh pekerja selain untuk menunjang pekerjaan juga 
sebagai fasilitas yang dapat melindungi, misalnya mereka melakukan kontak langsung dengan sampah agar tidak terkontaminasi dengan sampah yang kotor harus menggunakan slop tangan, selain itu juga lingkungan kerja yang di tempat umum seperti jalan raya mengakibatkan banyaknya risiko yang akan dihadapi seperti panasnya matahari, risiko lain seperti kecelakaan dijalan raya atau tempat umum.

Hasil wawancara dengan 5 orang tenaga kerja diatas memberikan sedikit gambaran bahwa tidak semua pegawai yang menetap diorganisasi ini senang atau memiliki komitmen seperti yang disampaikan oleh putu, nyoman, komang, made dan wayan. Salah satu penyebabnya karena jumlah dari kompensasi yang terima. Hasil ini juga memiliki keterkaitan dengan teori pertukaran sosial (Social Exchange Theory) juga merupakan pandangan tenaga kerja ketika pegawai telah diperlakukan dengan baik oleh organisasi, mereka akan cenderung untuk melakukan balas budi terhadap organisasi dengan bersikap dan berperilaku positif. Seperti halnya jika kompensasi yang diberikan oleh organisasi kepada tenaga kerja sesuai mereka akan merasa senang bekerja di organisasi ini.

Kompensasi berupa upah yang diterima oleh tenaga kerja khususnya pada bidang pengelolaan sampah, limbah bahan berbahaya dan beracun dan peningkatan kapasitas paling rendahhanyalah Rp. 29.000 per hari. Kopensasi yang mereka terima pada saat ini di bawah ketentuan UMK Kabupaten Tabanan yaitu sebesar Rp. 2.400.000 selama 25 hari kerja sedangkan yang di terima oleh tenaga kerja hanya Rp. 870.000 selama 30 hari kerja. Sangatlah tidak sesuai dengan ketentuan pemerintah mengenai UMK yang sudah di tetapkan. Selain itu jika dilihat dari proporsi jam kerja normal menurut UU No. 13 Tahun 2003 paragraf keempat, jam kerja normal yaitu 6 hari kerja sedangkan pada organisasi ini diterapkan 7 hari kerja yang mana berarti tidak ada hari libur untuk para tenaga kerja jelas ini melanggar aturan yang sudah ditetapkan pemerintah terkait dengan waktu kerja.

Pembahasan kedua yakni keselamatan dan kesehatan kerja merupakan salah satu perlindungan tenaga kerja yang diatur dalam UU No. 13 Tahun 2003 yang berisikan tentang prosedur keselamatan dan kesehatan kerja, dengan ini diharapkan tenaga kerja akan mencapai ketahanan fisik, daya kerja dan tingkat kesehatan yang tinggi sehingga produktivitas kerja semakin meningkat. UU ini juga memiliki hubungan dengan teori kebutuhan hierarki dimana rasa aman merupakan salah satu faktor penting agar tenaga kerja merasa aman dan nyaman didalam menjalankan tugasnya. Beberapa hal yang belum di terapkan oleh organisasi salah satunya tidak tersedianya jaminan kesehatan jiwa, hal ini merupakan sesuatu yang sangat dibutuhkan oleh tenaga kerja mengingat resiko kerja yang mereka hadapi baik itu karena sampah atau pun karena kecelakaan kerja saat melakukan pekerjaan di lapangan. Seperti yang penulis amati di lapangan tenaga kerja khususnya yang menyapu disekitar jalanan tidak dilengkapi dengan rompi dengan warna yang menyala sebagai pertanda jika ada orang yang sedang melakukan pekerjaan disekitar sana yang gunanya mengurangi kecelakaan kerja. Jika ketentuan-ketentuan seperti ini tidak dilaksanakan maka pemberi kerja akan mendapatkan sanksi seperti yang sudah ditetapkan pada UU No. 1 Tahun 1970 pada BAB XI pasal 15 (Suartha \& Sintaasih, 2015). 
Komitmen para tenaga kerja ini sebenarnya tidak lepas dari faktor tidak adanya pilihan lain karna mengingat tingkat pendidikan, pengalaman kerja dan umur yang sudah tidak muda lagi, mau tidak mau mereka akan tetap tinggal diorganisasi tersebut. Sedangkan dari segi kompensasi dan keselamatan kesehatan kerja masih ada hal-hal yang belum diberikan oleh organisasi kepada pekerja seperti kompensasi yang rendah tetapi risiko kerja yang tinggi kemudian dari keselamatan kesehatan kerja tidak adanya jaminan asuransi kesehatan.

Berdasarkan dari kajian yang telah dikemukakan di atas menimbulkan ketertarikan untuk mengetahui apakah ada hubungan antara kompensasi, keselamatan kesehatan kerja terhadap komitmen organiasional di Dinas Lingkungan Hidup Kabupaten Tabanan sehingga dapat dirumuskan sebagai berikut. Berdasarkan latar belakang yang sudah dijabarkan di atas tentang dampak kompensasi dan keselamatan kesehatan kerja terhadap komitmen organisasi, maka dapat disusun rumusan masalah sebagai berikut : 1) Bagaimana kompensasi berpengaruh terhadap komitmen organisasional? 2) Bagaimana keselamatan kesehatan kerja berpengaruh terhadap komitmen organisasional?

Teori yang mendasari penelitian ini adalah teori pertukaran sosial yang pertama kali dikemukakan oleh George C Homans yang dikembangkan oleh Pekelompok. Teori ini didasarkan pada hubungan yang semakin erat sampai pada saling percaya, loyal, dan saling berkomitmen antara kedua belah pihak (Tarigan, 2015). Teori pertukaran sosial (Social Exchange Theory) juga merupakan pandangan tenaga kerja ketika pegawai telah diperlakukan dengan baik oleh organisasi, mereka akan cenderung untuk melakukan balas budi terhadap organisasi dengan bersikap dan berperilaku positif, Bhatti (2011) juga mengemukakakn jika karyawan diberikan kompensasi yang sesuai maka karyawan tersebut akan memiliki komitmen organisasional yang tinggi.

Sopiah (2013) mengatakan salah satu cara yang digunakan oleh manajemen untuk meningkatkan kinerja, untuk memotivasi, meningkatkan kepuasan kerja, dan loyalitas pegawai adalah dengan melalui kompensasi. Berdasarkan UU No. 13 Tahun 2003 (BAB 1 ayat 10) kompensasi adalah kemampuan kerja setiap individu yang mencakup aspek pengetahuan, keterampilan, dan sikap kerja yang sesuai dengan standar yang ditetapkan. Kompensasi juga dapat diartikan sebagai penghargaan yang diberikan perusahaan kepada karyawannya agar kinerja yang dihasilkan karyawan dapat meningkat, kompensasi juga sifatnya tidak tetap dan selalu berubah-ubah sesuai dengan ketentuan yang ditetapkan perusahaan (Yusnita \& Sari, 2014). Pegawai yang memiliki komitmen tinggi akan bersungguh-sungguh dalam bekerja dan memiliki loyalitas terhadap organisasi. Bhatti (2011) menemukan bahwa jika karyawan diberikan kompensasi yang sesuai dengan ketentuan yang berlaku maka karyawan tersebut akan memiliki komitmen organisasional yang tinggi. Riana \& Wirasedana (2016), Darma \& Supriyanto (2017), Nawawi et al. (2018) dan Rizal et al. (2014) menemukan kompensasi berpengaruh signifikan terhadap komitmen organisasional. Hazra et al. (2018), Parashakti et al. (2017), Tarus (2016), Milgo et al. (2014) dan Praveena \& Monica (2017) menemukan hasil kompensasi menunjukan pengaruh signifikan dengan komitmen karyawan. Kee et al. (2016) menemukan bahwa hubungan yang signifikan antara kompensasi finansial seperti gaji, bonus dan 
uang muka terhadap komitmen organisasional, yang paling dominan diantara ketiga kompensasi tersebut adalah uang muka dalam penelitian ini. Berdasarkan hasil empiris pada penelitian di atas, dapat diajukan hipotesis dalam penelitian ini adalah

$\mathrm{H}_{1} \quad$ : Kompensasi berpengaruh positif terhadap komitmen organisasional.

Smith \& Sonesh (2011) mengemukakan bahwa pelatihan keselamatan kesehatan dan kerja (K3) mampu menurunkan risiko terjadinya kecelakaan kerja. Semakin besar pengetahuan karyawan akan K3 maka semakin kecil terjadinya resiko kecelakaan kerja, demikian sebaliknya semakin minimnya pengetahuan karyawan akan K3 maka semakin besar resiko terjadinya kecelakaan kerja. Menurut Erfa \& Kasmiruddin (2014) program keselamatan dan kesehatan kerja (K-3) dipandang penting untuk dilaksanakan oleh perusahaan sebagai upaya meminimalkan kecelakaan kerja. Keselamatan dan kesehatan kerja merupakan hal yang penting bagi perusahaan, karena dampak kecelakaan dan penyakit kerja tidak hanya merugikan karyawan, tetapi juga perusahaan baik secara langsung maupun tidak langsung.

Damayanthi \& Sintaasih (2016) mengatakan perusahaan yang rentan terhadap risiko kecelakaan kerja perlu secara berkesimanbungan mempertahankan berkaitan dengan pengetahuan dan kondisi kerja tiap individu. Wu (2008) menyatakan bahwa kinerja keselamatan adalah sistem kinerja manajemen keselamatan global yang dioperasikan dan diukur oleh organisasi keselamatan, manajemen keselamatan, keamanan peralatan, keselamatan dalam praktek pelatihan, keselamatan evakuasi pelatihan, kecelakaan penyelidikan, dan ukuran statistik kecelakaan.

K3 merupakan suatu masalah yang sangat signifikan untuk mencapai tujuan suatu organisasi (Daulay \& Ristiani, 2015). Ketika karyawan merasa terjamin keselamatan dan kesehatan kerja dan disertai dengan pemberian insentif maka ekspektasi terhadap karyawan agar bekerja seoptimal mungkin sangat tinggi. Sedangkan insentif seringkali diartikan sebagai penggerak atau pendorong yang diberikan dengan sengaja kepada para pekerja, agar dalam diri mereka timbul semangat yang lebih besar untuk berprestasi. Insentif sebagai perangsang supaya para karyawan bekerja dengan penuh tanggung jawab sehingga kinerja karyawan dapat tercapai (Munandar et al., 2014).

Damayanthi \& Sintaasih (2016) juga mengatakan upaya proaktif manajemen perusahaan untuk menciptakan program keselamatan dan kesehatan kerja yang baik dapat mendorong karyawan untuk terus mengabdi dan memiliki keterikatan secara emosional dengan perusahaan. Penelitian yang dilakukan oleh Budianto (2014) menunjukkan bahwa kesehatan kerja berpengaruh signifikan terhadap komitmen organisasional. Sedangkan menurut Junaedi et al. (2013) membuktikan bahwa keselamatan kerja berpengaruh signifikan terhadap komitmen organisasional. Berdasarkan hasil empiris pada penelitian di atas, dapat diajukan hipotesis dalam penelitian ini adalah

$\mathrm{H}_{2}$ : Keselamatan kesehatan kerja berpengaruh positif terhadap komitmen organisasional 


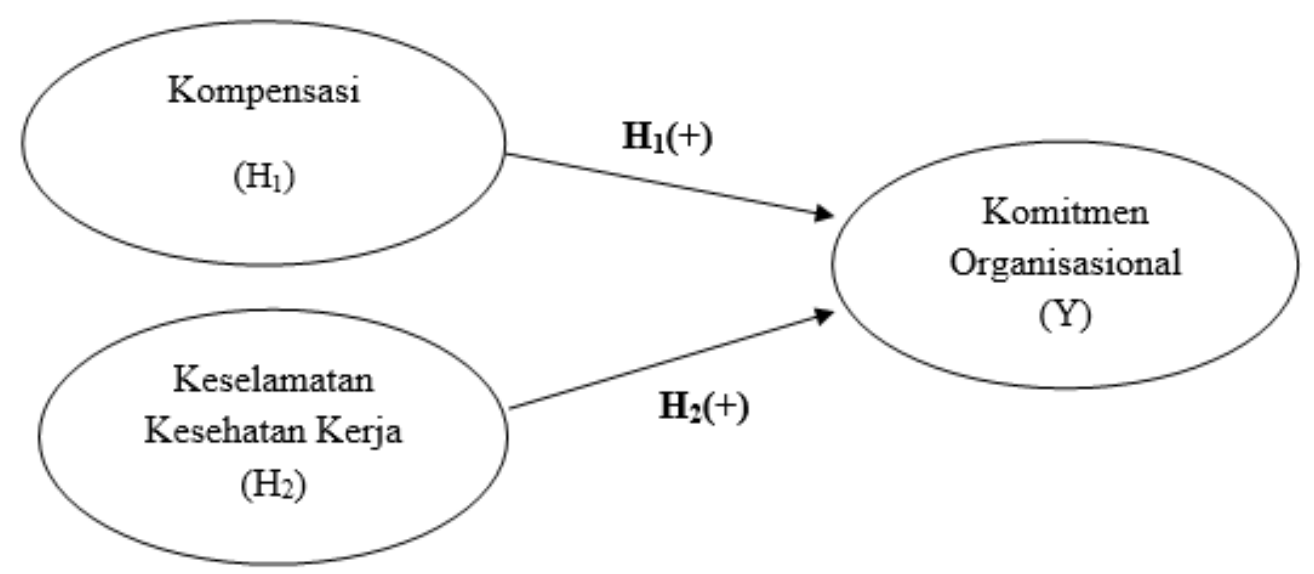

Gambar 1. Kerangka Konseptual Penelitian

\section{METODE PENELITIAN}

Berdasarkan permasalahan yang diteliti, penelitian ini digolongkan pada penelitian asosiatif (hubungan), yaitu penelitian yang bertujuan untuk mengetahui hubungan dari variabel atau lebih. Penelitian ini menggunakan pendekatan kuantitatif yang bersifat asosiatif untuk meneliti data yang bersifat statistik serta menguji suatu hipotesis, dengan kuesioner sebagai istrumen yang dipakai. Hal ini dikarenakan terdapat hubungan kausal (sebab-akibat) antara variabel bebas $\left(\mathrm{X}_{1}\right.$ dan $\mathrm{X}_{2}$ ) yaitu kompensasi dan keselamatan kesehatan kerjadengan variabel terikat (Y) yaitu komitmen organisasional. Dinas Lingkungan Hidup Kabupaten Tabanan berlokasi di Jl. Pahlawan No.1 A, Delod Peken, Kec. Tabanan, Kabupaten Tabanan. Sedangkan lokasi pengambilan sampel kuesioner tersebar dibeberapa wilayah titik-titik penempatan para petugas kebersihan. Objek didalam penelitian ini adalah 1) kompensasi, 2) keselamatan kesehatan kerja dan 3) komitmen organisasional. Variabel bebas pada penelitian ini adalah kompenasi $\left(\mathrm{X}_{1}\right)$ dan keselamatan kesehatan kerja $\left(\mathrm{X}_{2}\right)$. Veriabel terikat pada penelitian ini adalah komitmen organisasional (Y).

Loyalitas atau komitmen organisasional merupakan keinginan untuk tetap bekerja pada organisasi sebagai bentuk rasa cinta individu tersebut terhadap organisasi. Komitmen organisasional di ukur menggunakan tiga indikator yakni 1) Komitmen afektif (affective commitment) ( $\left.\mathrm{Y}_{1.1}\right)$ 2) Komitmen berkelanjutan (continuance commitment) ( $\left.\mathrm{Y}_{1.2}\right) 3$ ) Komitmen normatif (normative commitment) (Y1.3) Kompensasi merupakan sesuatu yang diberikan oleh perusahaan terhadap pegawai sebagai bentuk apresiasi untuk partisipasi di dalam perusahaan. UU No. 13 Tahun 2003 (BAB 1 ayat 10) juga menyatakan kompensasi adalah kemampuan kerja setiap individu yang mencakup aspekpengetahuan, keterampilan, dan sikap kerja yang sesuai dengan standar yang ditetapkan. Berdasarkan UU No. 13 tahun 2003 pasal 88 menuliskan beberapa elemen yang berkaitan dengan kompensasi yakni: 1) Upah minimum $\left(\mathrm{X}_{1.1}\right)$ 2) Bentuk dan cara menjalankan upah $\left(\mathrm{X}_{1.2}\right)$ 3) Sturktur dan skala pengupahan yang proporsional $\left(\mathrm{X}_{1.3}\right)$ 4) Upah untuk perhitungan pajak penghasilan $\left(\mathrm{X}_{1.4}\right)$ 
Keselamatan kesehatan kerja merupakan salah satu perlindungan tenaga kerja yang diatur dalam UU No. 13 Tahun 2003. Keselamatan kesehatan kerja dapat diartikan juga sebagai pengawasan terhadap orang, mesin, mineral, dan metode yang mencakup lingkungan kerja agar pekerja tidak mengalami cidera. Adapun elemen ataupun syarat dari K3 menurut UU 1970 yakni : 1) Mencegah dan mengurangi kecelakaan kerja $\left(X_{2.1}\right)$ 2) Memberi pertolongan pada kecelakaan kerja $\left(\mathrm{X}_{2.2}\right)$ 3) Memberikan alat-alat perlindunganpada tenaga kerja $\left(\mathrm{X}_{2.3}\right)$ 4) Tanggung jawab pengurus terdiri dari kewajibkan memeriksakan kesehatan badan, kondisi mental dan kemampuan fisik dari tenaga kerja $\left(\mathrm{X}_{2.4}\right)$ 5) Pengawasan pecelakaan kerja terdiri dari kewajibkan melaporkan tiap kecelakaan yang terjadi dalam tempat kerja $\left(\mathrm{X}_{2.5}\right)$

Populasi dari penelitian ini adalah 264 tenaga kerja di Dinas Lingkungan Hidup Kabupaten Tabanan. Jumlah sampel yang digunakan dalam penelitian ini ditentukan dengan menggunakan pendekatan slovin berdasarkan jumlah populasi tenaga kerja Dinas Lingkungan Hidup. Didapatkan jumlah total sampel penelitian sebanyak 159 sampel dengan menggunakan teknik random sampling. Metode pengumpulan data yang digunakan dalam penelitian ini dengan cara wawancara dan kuesioner. Data kuantitatif dalam penelitian ini adalah jumlah karyawan, lama masa kerja yang didapat dari Dinas Lingkungan Hidup Kabupaten Tabanan. Data kualitatif padapenelitian ini berupa sejarah dan struktur organisasi di Dinas Lingkungan Hidup Kabupaten Tabanan.Sumber primer dari penelitian ini adalah karyawan di Dinas Lingkungan Hidup Kabupaten Tabanan yang diukur menggunakan kuesioner. Sumber sekunder dalam penelitian ini adalah data yang sudah ada di Dinas Lingkungan Hidup Kabupaten Tabanan.

\section{HASIL DAN PEMBAHASAN}

Karakteristik Responden Berdasarkan Usia. Sebagian besar responden berusia diantara $44-48$ tahun dengan persentase sebesar 17,05 persen, sedangkan untuk kelompok usia terendah yaitu pada usia 74 - 78 tahun dengan persentase 2,27 persen dimana hal ini berarti usia tenaga kerja yang produktif di Dinas Lingkungan Hidup Kabupaten Tabanan yaitu berumur antara $44-48$ tahun.

Karakteristik Responden Berdasarkan Jenis Kelamin. Sebagian besar responden adalah perempuan sebanyak 109 orang dengan persentase 68,55 persen, sedangkan sisanya laki - laki sebanyak 50 orang dengan persentase 31,45 persen.

Karakteristik Responden Berdasarkan Pendidikan Terakhir. Responden berdasarkan pendidikan terakhir adalah tidak mengenyam pendidikan sebanyak 105 orang dengan persentase 39,77 persen. Hal ini sangat disayangkan karena ternyata banyak pekerja yang tidak mengenyam pendidikan. Sementara itu sebanyak 85 orang pekerja memiliki pendidikan terakhir SMA, 37 orang memiliki pendidikan terakhir SMP dan sebanyak 36 orang mengenyam pendidikan terakhir SD. Hanya sebanyak 2 orang saja yang memiliki pendidikan terakhir Diploma dan Sarjana. Pendidikan terakhir tenaga kerja di Dinas Lingkungan Hidup Kabupaten Tabanan masih tergolong rendah. 
Karakteristik Responden Berdasarkan Bagian. Sejumlah 25,76 persen pekerja bertugas sebagai tenaga sapu barat atau sebanyak 68 orang. Selanjutnya sebanyak 67 orang bertugas tenaga sapu timur dengan presentase 25,38 persen, 31 orang bertugas sebagai tenaga sapu pasar di Kecamatan dengan presentase 11,74 persen. Sebanyak 6 orang bertugas sebagai tenaga sapu pasar Senggol Gajah Mada dengan presentase 2,27 persen dan sebanyak 7 orang bertugas sebagai tenaga motor gerobak sampah dengan presentase 2,65.

Karakteristik Responden Berdasarkan Masa Kerja. Masa kerja terbanyak yaitu 5 sampai 10 tahun adalah 79 orang dengan persentase 49,69, kemudian jumlah kedua 10 sampai 15 tahun yaitu 35 orang dengan persentase 22,01, selanjutnya lebih dari 15 tahun sebanyak 34 orang dengan persentase 21,38 dan terakhir hanya 1 sampai 5 tahun sebanyak 11 orang dengan presentase 6,92. Masa kerja tenaga kerja di Dinas Lingkungan Hidup Kabupaten Tabanan masih tergolong baik karena mereka tetap bisa tinggal untuk waktu yang lumayan lama yaitu kurang lebih 10 tahunan dengan kompensasi yang tidak mencuk.

Instrumen dikatakan valid jika korelasi item total bernilai positif dan nilainya lebih dari $0,03(\mathrm{r}>30)$. Hasil uji validitas instrument penelitian. Data menunjukkan bahwa setiap butir pernyataan pada kuesioner memiliki skor lebih dari 0,03. Hasil uji validitas menghasilkan korelasi terkecil sebesar 0,302 dan korelasi yang terbesar yaitu 0,924 . Uji validitas menunjukkan bahwa kuesioner layak digunakan dalam penelitian.

Tabel 1.

Uji Reliabilitas

\begin{tabular}{ccc}
\hline Variabel & Cronbach'sAlpha & Keterangan \\
\hline Kompensasi $\left(\mathrm{X}_{1}\right)$ & 0,758 & Reliabel \\
Kesehatan Keselamatan Kerja $\left(\mathrm{X}_{2}\right)$ & 0,758 & Reliabel \\
Komitmen Organisasional $(\mathrm{Y})$ & 0,749 & Reliabel \\
\hline
\end{tabular}

Sumber: Data primer, 2019

Hasil uji reliabilitas yang disajikan menunjukkan bahwa seluruh instrument penelitian memiliki koefisien Cronbach's Alphalebih dari 0,6. Sehingga dapat dinyatakan bahwa seluruh variabel memenuhi syarat reliabilitas dan dapat digunakan dalam penelitian ini.

Faktor 1 (Kehancuran organisasi berhubungan dengan harga diri pekerja), nilai eigen $=11,895$ terbentuk oleh: 1 ) Indikator 5 (Masalah organisasi) dengan nilai loading $=0,406$. Indikator 6 (Tidak mudah terikat dengan organisasi lain) dengan nilai loading $=0,699$. Indikator 7 (Hubungan antar tenaga) dengan nilai loading $=0,800$. Indikator 8 (Setiap saat memikirkan kondisi organisasi) dengan nilai loading $=0,752$. Indikator 9 (Organisasi memiliki arti) dengan nilai loading $=0,762$. Indikator 10 (Kehancuran organisasi berhubungan dengan harga diri pekerja) dengan nilai loading $=0,840$. Indikator 11 (Keluar dari organisasi tidak menjamin memperoleh pekerjaan pengganti) dengan nilai loading $=0,714$. Indikator 12 (Perasaan malu bekerja sebagai mandor di organisasi) dengan nilai loading $=0,548$

Faktor 2 (Berhenti bekerja di organisasi ini membuatn penghasilan tidak cukup untuk memenuhi kebutuhan hidup), nilai eigen $=4,622$ terbentuk oleh: 
Indikator 16 (Perasaan malu bekerja sebagai tenaga sapu di organisasi) dengan nilai loading $=0,568$. Indikator 17 (Berhenti bekerja di organisasi ini membuatn penghasilan tidak cukup untuk memenuhi kebutuhan hidup) dengan nilai loading $=0,819$. Indikator 18 (Meninggalkan organsisasi menimbulkan kerugian financial) dengan nilai loading $=0,794$. Indikator 19 (Tetap bekerja di organisasi karena waktu kerja yang pendek) dengan nilai loading $=0,817$. Indikator 20 (Perasaan bangga bekerja di organisasi) dengan nilai loading $=0,714$. Indikator 22 (Memiliki peluang bekerja di organisasi lain) dengan nilai loading $=0,675$. Indikator 23 (Tetap bekerja di organisasi walaupun memiliki peluang bekerja di organisasi lain) dengan nilai loading $=0,532$

Faktor 3 (Perasaan bangga bekerja sebagai tenaga cikar), nilai eigen $=4,163$ terbentuk oleh: Indikator 27 (Perasaan bangga bekerja sebagai supir hunter) dengan nilai loading $=0,619$. Indikator 28 (Perasaan bangga bekerja sebagai tenaga motor gerobak) dengan nilai loading $=0,676$. Indikator 29 (Perasaan bangga bekerja sebagai tenaga cikar) dengan nilai loading $=0,825$. Indikator 30 (Perasaan bangga bekerja sebagai tenaga sapu) dengan nilai loading $=0,594$. Indikator 31 (Suka bekerja sebagai mandor) dengan nilai loading $=0,730$. Indikator 32 (Suka bekerja sebagai supir hunter) dengan nilai loading $=0,684$

Faktor 4 (Perasaan senang menghabiskan waktu sebagai tenaga sapu), nilai eigen $=1,629$ terbentuk oleh: Indikator 1 (Perasaan senang menghabiskan waktu sebagai supir hunter) dengan nilai loading $=0,573$. Indikator 2 (Perasaan senang menghabiskan waktu sebagai tenaga motor gerobak) dengan nilai loading $=0,644$. Indikator 3 (Perasaan senang menghabiskan waktu sebagai tenaga cikar) dengan nilai loading $=0,788$. Indikator 4 (Perasaan senang menghabiskan waktu sebagai tenaga sapu) dengan nilai loading $=0,809$

Faktor 5 (Berpindah pekerjaan lain tidak memberikan manfaat), nilai eigen $=1,583$ terbentuk oleh: Indikator 24 (Pendapatan dengan pekerjaan lain lebih tinggi) dengan nilai loading $=0,699$. Indikator 25 (Berpindah pekerjaan lain tidak memberikan manfaat) dengan nilai loading $=0,759$. Indikator 26 (Perasaan bangga bekerja sebagai mandor) dengan nilai loading $=0,701$. Indikator 33 (Suka bekerja sebagai supir tenaga motor gerobak) dengan nilai loading $=0,594$. Indikator 34 (Suka bekerja sebagai supir tenaga cikar) dengan nilai loading = 0,540

Faktor 6 (Tidak diwajibkan tetap bekerja di organisasi ini), nilai eigen $=$ 1,409 terbentuk oleh: Indikator 21 (Suka bekerja pada organisasi) dengan nilai loading $=0,541$. Indikator 35 (Suka bekerja sebagai tenaga sapu) dengan nilai loading $=0,613$. Indikator 36 (Tidak akan meninggalkan pekerjaan untuk memperoleh gaji yang lebih tinggi) dengan nilai loading $=0,586$. Indikator 37 (Tidak diwajibkan tetap bekerja di organisasi ini) dengan nilai loading $=0,638$

Faktor 7 (Malu bekerja sebagai tenaga cikar), nilai eigen $=1,409$ terbentuk oleh: Indikator 13 (Malu bekerja sebagai supir hunter) dengan nilai loading = 0,612. Indikator 14 (Malu bekerja sebagai tenaga motor gerobak) dengan nilai loading $=0,685$. Indikator 15 (Malu bekerja sebagai tenaga cikar) dengan nilai loading $=0,691$. Faktor ini diberi label pelaksanaan tugas dari atasan sebagai kontributor dominan. 
Model faktor mencerminkan dimensi konstruk yang dinilai layak. Hasil analisis yang menunjukkan jumlah data sampel memadai dengan ditunjukkannya nilai Kaiser Meyer Olkin Measure of Sampling Adequacy $(\mathrm{KMO})=0,740$ dan nilai Bartlett test $=1645,730$ dengan sig. $(0,000)<0,05$. Indikator dikelompokkan menjadi 7 faktor berdasarkan nilai eigen value $>1$ keseluruhan faktor mampu menjelaskan variasi total 71,674, maka komitmen organisasional dinilai memiliki validitas memadai.

Faktor 1 (Upah di bagian mandor memuaskan), nilai eigen $=4,650$ terbentuk oleh: Indikator 1.1 (Upah yang diterima per harinya) dengan nilai loading $=0,722$. Indikator 1.2 (Upah yang diberikan cukup untuk memenuhi kebutuhan hidup) dengan nilai loading $=0,706$. Indikator 1.3 (Upah di bagian mandor memuaskan) dengan nilai loading $=0,788$. Indikator 1.4 (Upah di bagian supir hunter memuaskan) dengan nilai loading $=0,725$. Indikator 1.5 (Upah di bagian motor gerobak memuaskan) dengan nilai loading $=0,722$. Indikator 1.11 (Pekerjaan tambahan memberikan penghasilan tambahan) dengan nilai loading $=$ 0,529. Indikator 1.12 (Penghasilan tambahan cukup untuk memenuhi kebutuhan hidup) dengan nilai loading $=0,533$

Faktor 2 (Upah sesuai dengan resiko kerja), nilai eigen $=1,684$ terbentuk oleh: Indikator 1.6 (Upah di bagian cikar memuaskan) dengan nilai loading $=$ 0,552 . Indikator 1.7 (Upah di bagian sapu memuaskan) dengan nilai loading $=$ 0,821. Indikator 1.8 (Upah sesuai dengan resiko kerja) dengan nilai loading $=$ 0,880. Faktor 3 (Pembayaran upah dilakukan tepat waktu), nilai eigen $=1,079$ terbentuk oleh: Indikator 1.9 (Pembayaran upah dilakukan tepat waktu) dengan nilai loading $=0,803$. Indikator 1.10 (Pekerjaan tambahan selain pekerjaan di organisasi) dengan nilai loading $=0,765$ Faktor ini diberi label upah sesuai dengan resiko kerja sebagai kontributor dominan.

Model faktor mencerminkan dimensi konstruk yang dinilai layak. Hasil analisis yang menunjukkan jumlah data sampel memadai dengan ditunjukkannya nilai Kaiser Meyer Olkin Measure of Sampling Adequacy $(\mathrm{KMO})=0,816$ dan nilai Bartlett test $=246,811$ dengan sig. $(0,000)<0,05$. Indikator dikelompokkan menjadi 3 faktor berdasarkan nilai eigen value $>1$ keseluruhan faktor mampu menjelaskan variasi total 61,768, maka kompensasi dinilai memiliki validitas memadai.

Faktor 1 (Pembaharuan alat kerja), nilai eigen $=4,821$ terbentuk oleh: Indikator 2.1 (Penetapan peraturan keselamatan kerja) dengan nilai loading = 0,517. Indikator 2.2 (Prosedur bekerja yang aman) dengan nilai loading $=0,509$. Indikator 2.15 (Tong sampah layak) dengan nilai loading $=0,787$. Indikator 1.16 (Pengarahan tentang pentingnya alat pelindung diri) dengan nilai loading $=0,742$. Indikator 1.17 (Pembaharuan alat kerja) dengan nilai loading $=0,766$

Faktor 2 (Pemberian topi), nilai eigen $=2,178$ terbentuk oleh: Indikator 2.6 (Pemberian topi) dengan nilai loading $=0,750$. Indikator 2.7 (Pemberiansepatu boots) dengan nilai loading $=0,693$. Indikator 2.18 (Pelaporan kecelakaan) dengan nilai loading $=0,523$. Indikator 2.19 (Sarana pertolongan pertama) dengan nilai loading $=0,581$. Faktor 3 (Pemberian seragam), nilai eigen $=1,875$ terbentuk oleh: Indikator 2.4 (Pemberian seragam) dengan nilai loading $=0,861$. Indikator 2.5 (Pemberian slop tangan) dengan nilai loading $=0,853$ 
Faktor 4 (Kondisi serok), nilai eigen $=1,489$ terbentuk oleh: Indikator 2.11 (Kondisi sapu) dengan nilai loading $=0,562$. Indikator 2.12 (Kondisi serok) dengan nilai loading $=0,752$. Indikator 2.13 (Kondisi mobil hunter) dengan nilai loading $=0,622$. Faktor 5 (Mengetahui cara mengunakan peralatan keselamatan kerja), nilai eigen $=1,182$ terbentuk oleh: Indikator 2.10 (Mengetahui cara mengunakan peralatan keselamatan kerja) dengan nilai loading $=0,790$. Indikator 2.14 (Kondisi motor) dengan nilai loading $=0,730$. Faktor 6 (Mematuhi peraturan keselamatan kerja), nilai eigen $=1,119$ terbentuk oleh: Indikator 2.3 (Mematuhi peraturan keselamatan kerja) dengan nilai loading $=0,817$. Indikator 2.8 (Pemberian masker) dengan nilai loading $=0,463$. Indikator 2.9 (Rasa aman) dengan nilai loading $=0,501$. Faktor ini diberi label pemberian seragam sebagai kontributor dominan. Model faktor mencerminkan dimensi konstruk yang dinilai layak. Hasil analisis yang menunjukkan jumlah data sampel memadai dengan ditunjukkannya nilai Kaiser Meyer Olkin Measure of Sampling Adequacy (KMO) $=0,706$ dan nilai Bartlett test $=378,888$ dengan sig. $(0,000)<0,05$. Indikator dikelompokkan menjadi 6 faktor berdasarkan nilai eigen value $>1$ keseluruhan faktor mampu menjelaskan variasi total 66,649, maka keselamatan kesehatan kerja dinilai memiliki validitas memadai

Penilaian responden dengan menggunakan 3 indikator (data lampirkan 1) yang diuraikan ke dalam 37 pernyataan terhadap variabel komitmen organisasional tenaga kerja Dinas Lingkungan Hidup Kabupaten Tabanan. Nilai rata-rata 2,73 yang berarti komitmen tenaga kerja berada pada tingkat loyalitas yang cukup. Pernyataan mengenai komitmen afektif memiliki rata rata skor lebih rendah dari nilai skor midel komitmen secara umum yakni dibawah 3 yang artinya komitmen afektif para tenaga kerja di Dinas Lingkungan Hidup Kabupaten Tabanan saat ini tergolong rendah, responden mengungkapkan bahwa mereka tidak merasa senang bekerja sebagai supir hunter, supir tenaga motor gerobak, tenaga cikar dan tenaga sapu. Responden juga mengungkapkan bahwa mereka merasa malu bekerja sebagai supir hunter, supir tenaga motor gerobak, tenaga cikar dan tenaga sapu. Responden memiliki ikatan emosional yang rendah dengan organiasi ini karena mereka tidak peduli dengan masalah organisasi, mereka tidak memikirkan organisasi, dan mereka juga mudah terikat dengan organisasi lain. Responden dari bagian supir tenaga motor gerobak, supir tenaga cikar dan tenaga sapu tidak memiliki kebanggaan terhadap pekerjaannya yang sekarang disisi lain supir tenaga cikar dan tenaga sapu juga tidak suka bekerja menjadi tenaga kebersihan di Dinas Lingkungan Hidup Kabupaten Tabanan.

Komitmen berkelanjutan tenaga kerja diorganisasi ini memperoleh respon yang positif, mereka tetap bekerja diorganisasi ini karena responden merasa akan mengalami kerugian finansial jika berhanti dari pekerjaan ini selain itu mereka juga mempertimbangkan waktu kerja yang pendek hanya 4 jam kerja. Komitmen normatif diorganisasi ini dapat juga dapat dikatakana rendah hal tersebuat termuat didalam pernyataan yang masing-masing mengungkapkan skor 2,06 untuk pernyataan tidak akan meninggalkan pekerjaan ini jika memperoleh gaji yang lebih dari organisasi ini yang artinya tenaga kerja akan keluar dari organisasi ini jika ada tawaran pekerjaan lain yang memberikan gaji yang lebih besar, tenaga kerja juga mengungkapkan sangat setuju pada bertanyaan selanjutnya tentang 
tidak diwajibkan untuk bekerja di organisasi ini. Sehingga dapat disimpulkan komitmen tenaga kerja diorganisasi ini rendah tapi mereka tidak keluar dari organisasi dengan alasan tidak adanya pilihan pekerjaan lain.

Penilaian responden dengan menggunakan 4 indikator (data lampiran 2) yang diuraikan ke dalam 12 pernyataan terhadap variabel kompensasi tenaga kerja Dinas Lingkungan Hidup Kabupaten Tabanan. Nilai rata-rata sebesar 2,53 yang artinya tenaga kerja tidak puas dengan kompensasi yang diberikan untuk saat ini. Data respon menunjukkan bahwa upah yang diterima tenaga sapu adalah $\mathrm{Rp}$. 29.000/harinya. Nilai itu tidak cukup untuk memenuhi kebutuhan hidup, hal yang sama juga disampaikan oleh mandor, supir hunter, supir tenaga motor gerobak, tenaga cikar. Tenaga kerja juga merasa upah yang diberikan tidak sesuai dengan resiko kerja yang mereka hadapi di lapangan, akan tetapi mereka merasa cukup puas dengan pembayaran upah yang dikatakan tepat waktu yakni awal bulan jika tidak bersamaan dengan hari libur. Hasil analisis data menyatakan bahwa responden mereka memiliki pekerjaan tambahan diluar menjadi tenaga kebersihan dan pekerjaan tambahan tersebut diakui memberikan penghasilan tambahan dan dapat memenuhi atau melengkapi kebutuhan hidup mereka. Dapat disimpulkan bahwa mereka tidak puas dengan kompensasi yang diberikan oleh Dinas Lingkungan Hidup Kabupaten Tabanan.

Penilaian responden dengan menggunakan 5 indikator (data lampiran 3) yang diuraikan ke dalam 19 pernyataan terhadap variabel keselamatan dan kesehatan kerja para tenaga kerja Dinas Lingkungan Hidup Kabupaten Tabanan. Data responden menyatakan bahwa organisasi menerapkan peraturan K3 dengan baik sehingga para tenaga kerja memahami prosedur bekerja dengan baik dan mereka dapat menggunakan peralatan kerja sesuai dengan fungsinya. Organisasi juga memberikan fasilitas kerja seperti seragam, slop tangan, topi, sepatu boots, masker sehingga mereka merasa aman di dalam melaksanakan tugas mereka. Peralatan kerja seperti sapu, serok, mobil hunter, motor, dan tong sampah juga disedikan dengan kondisi yang layak dan diganti secara teratur jika sudah ada yang rusak. Hasil analisis data ini dapat disimpulkan bahwa keselamatan dan kesehatan kerja pada organisasi sudah baik.

Tabel 2.

Hasil Uji Normalitas

\begin{tabular}{lcc}
\hline \multicolumn{1}{c}{ Variabel } & Signifikansi & Kesimpulan \\
\hline Kompensasi (X1) & 0,200 & Normal \\
Kesehatan Keselamatan Kerja (X2) & 0,057 & Normal \\
Komitmen Organisasional (Y) & 0,200 & Normal \\
\hline
\end{tabular}

Sumber: Data Primer (data diolah), 2019

Berdasarkan hasil pengujian normalitas, dapat dilihat bahwa nilai signifikansi tiap-tiap variabel lebih besar dari $\alpha=0,05$. Dengan demikian, dapat disimpulkan bahwa ketiga variabel penelitian ini berdistribusi normal, sehingga dapat dianalisa lebih lanjut. 
Tabel 3.

Hasil Uji Multikolinieritas

\begin{tabular}{lcc}
\hline \multicolumn{1}{c}{ Model } & \multicolumn{2}{c}{ Collinearity Statistics } \\
\cline { 2 - 3 } & Tolerance & VIF \\
\hline Kompensasi & .871 & 1.148 \\
Keselamatan Kesehatan Kerja & .871 & 1.148 \\
\hline Sing
\end{tabular}

Sumber: Data Primer (data diolah), 2019

Variabel kompensasi dan variabek keselamatan kesehatan kerja memiliki tolerance lebih besar dari $0,10(0,871>0,10)$ dan VIF lebih kecil dari 10 $(1,148<10)$. Dengan demikian dapat dinyatakakan tidak terjadi multikolinieritas.

Tabel 4.

Hasil Uji Heteroskedastisitas

\begin{tabular}{|c|c|c|c|c|c|}
\hline \multirow[t]{2}{*}{ Model } & \multicolumn{2}{|c|}{$\begin{array}{l}\text { Unstandardized } \\
\text { Coefficients }\end{array}$} & \multirow{2}{*}{$\begin{array}{c}\begin{array}{c}\text { Standardized } \\
\text { Coefficients }\end{array} \\
\text { Beta } \\
\end{array}$} & \multirow[t]{2}{*}{$\mathbf{T}$} & \multirow[t]{2}{*}{ Sig. } \\
\hline & B & Std. Error & & & \\
\hline (Constant) & -3.786 & 3.211 & & -1.179 & .240 \\
\hline Kompensasi (X1) & .020 & .055 & .030 & .358 & .721 \\
\hline $\begin{array}{l}\text { Keselamatan Kesehatan } \\
\text { Kerja (X2) }\end{array}$ & .085 & .046 & .155 & 1.832 & .069 \\
\hline
\end{tabular}

Sumber: Data Primer (data diolah), 2019

Nilai Sig. dari variabel kompensasi $\left(\mathrm{X}_{1}\right)$ sebesar 0,721, keselamatan kesehatan kerja $\left(\mathrm{X}_{2}\right)$ sebesar 0,069. Nilai tersebut lebih besar dari 0,05 yang berarti tidak terdapat pengaruh antara variabel independen terhadap absolute residual. Dengan demikian, model yang dibuat tidak mengandung gejala heteroskedastisitas.

Tabel 5.

Hasil Uji Kelayakan Model (Uji F)

\begin{tabular}{lrrrrr}
\hline \multicolumn{1}{c}{ Model } & Sum of Squares & \multicolumn{1}{c}{ Df } & Mean Square & \multicolumn{1}{c}{ F } & Sig. \\
\hline Regression & 1568.280 & 2 & 784.140 & 58.679 & .000 \\
Residual & 2084.676 & 156 & 13.363 & & \\
Total & 3652.956 & 158 & & & \\
\hline
\end{tabular}

Sumber: Data Primer (data diolah), 2019

Tabel 5. Dasar pengambilan keputusan yang digunakan uji $\mathrm{F}$ yaitu dengan membandingkan tingkat signifikan 0,05 . Jika nilai probabilitas $\leq 0,05$, maka dapat dikatakan terdapat model fit dengan data. Namun, jika nilai probabilitas > 0,05, maka model tidak fit dengan data (Ghozali, 2016:96). Hasil Uji F menunjukkan sebesar 58,679 > nilai tabel sebesar 3,05 denga Sig. 0,000. Hal ini berarti hipotesa awal ditolak sehingga hipotesa alternatif yang mengatakan ada pengaruh nyata dan signifikan antara kompensasi dan keselamatan kesehatan kerja terhadap komitmen organisasional. Dengan kata lain model regresi dalam penelitian ini layak untuk digunakan sebagai alat analisis dan variabel kompensasi $\left(\mathrm{X}_{1}\right)$, keselamatan kesehatan kerja $\left(\mathrm{X}_{2}\right)$ berpengaruh signifikan secara serempak terhadap variabel terikatkomitmen organisasional (Y) sehingga penelitian ini 
dapat dikatakan memenuhi uji kelayakan model atau model penelitian dinyatakan layak digunakan sebagai model regresi.

Tabel 6.

Hasil Analisis Koefisien Determinasi $\left(\mathbf{R}^{2}\right)$

\begin{tabular}{cccc}
\hline $\mathbf{R}$ & $\mathbf{R}$ Square & Adjusted R Square & Std. Error of the Estimate \\
\hline .655 & .429 & .422 & 3.656 \\
\hline Sumber: & Data Primer (data diolah), 2019 & &
\end{tabular}

Berdasarkan Tabel 6. dapat dilihat nilai Adjusted $R$ Square sebesar 0,422 sehingga dapat dihitung persentase kontribusi kompensasi, keselamatan kesehatan kerja terhadap komitmen organisasional sebesar $0,422 \times 100 \%=42,2 \%$ dengan sisa $57,8 \%$ dipengaruhi variabel lain diluar penelitian.

Tabel 7.

Hasil Analisis Regresi Linier Berganda

\begin{tabular}{lrrrrr}
\hline \multirow{2}{*}{ Model } & \multicolumn{2}{c}{$\begin{array}{c}\text { Unstandardized } \\
\text { Coefficients }\end{array}$} & $\begin{array}{c}\text { Standardized } \\
\text { Coefficients }\end{array}$ & T & Sig. \\
\cline { 2 - 4 } & \multicolumn{1}{c}{ B } & Std. Error & Beta & & \\
\hline (Constant) & 38.899 & 6.031 & & 6.450 & .000 \\
Kompensasi $\left(\mathrm{X}_{1}\right)$ & .499 & .104 & .312 & 4.817 & .000 \\
Keselamatan Kesehatan & .637 & .087 & .475 & 7.324 & .000 \\
Kerja $\left(\mathrm{X}_{2}\right)$ & & & & & \\
\hline
\end{tabular}

Sumber: Data Primer (data diolah), 2019

Dari data pada Tabel 7. diketahui bahwa nilai $\beta_{1}$ adalah sebesar 0,499 menunjukkan adanya pengaruh positif kompensasi $\left(\mathrm{X}_{1}\right)$ terhadap komitmen organisasional (Y). Nilai $\beta_{2}$ adalah sebesar 0,637 menunjukkan adanya pengaruh positif keselamatan kesehatan kerja $\left(\mathrm{X}_{2}\right)$ terhadap komitmen organisasional (Y).Dari hasil tersebut, maka variabel kompensasi, keselamatan kesehatan kerja berpengaruh terhadap komitmen organisasional tenaga kerja Dinas Lingkungan Hidup Kabupaten Tabanan.

Berdasarkan hasil regresi linear berganda, diketahui bahwa nilai signifikansi untuk variabel kompensasi yakni 0,000 kurang dari 0,05 $(0,000<0,05)$, dengan nilai $t$ hitung 4,817 yang dibandingkan dengan nilai $t$ tabel dengan derajat kebebasan $\mathrm{N}-\mathrm{k}=159-3=156$ dan signifikansi 0,05. Diperoleh nilai $\mathrm{t}$ tabel sebesar 1,975 sehingga nilai $t$-hitung $>t$-tabel $(4,817>1,975)$. Dengan demikian, $\mathrm{H}_{1}$ diterima sehingga secara parsial kompensasi berpengaruh positif terhadap komitmen organisasional. Berdasarkan hasil regresi linear berganda, diketahui bahwa nilai signifikansi untuk variabel keselamatan kesehatan kerja yakni 0,000 kurang dari $0,05(0,000<0,05)$, dengan nilai t hitung 7,324 yang dibandingkan dengan nilai $\mathrm{t}$ tabel dengan derajat kebebasan $\mathrm{N}-\mathrm{k}=159-3=156$ dan signifikan 0,05. Diperoleh nilai t tabel sebesar 1,975 sehingga nilai $t$-hitung $>t$ tabel $(7,324>1,975)$. Dengan demikian, $\mathrm{H}_{2}$ diterima sehingga secara parsial kesehatan keselamatan kerja berpengaruh positif terhadap komitmen organisasional. 
Hasil pengujian hipotesis membuktikan bahwa pekerja bidang kebersihan yang menjadi responden cukup loyal terhadap organisasi, loyalitas tersebut diuangkapkan dengan cara mereka tetep bekerja sebagai tenaga kebershan di Dinas Lingkungan Hidup Kabupaten Tabanan sehingga dapat dikatakana kompensasi berpengaruh positif terhadap komitmen organisasional. Kompensasi merupakan imbalan yang diterima pekerja untuk layanan atau kontribusi kepada organisasi mereka (Salisu et al., 2015). Kompensasi yang diberikan organisasi untuk saat ini tidak dapat memenuhi kebutuhan hidup, karena kurang dari nilai upah minimum kabupaten (UMK) di tabanan yang nilainya Rp 2.400.000 dan upah yang di berikan tidak sesuai dengan resiko kerja yang mereka hadapi di lapangan.

Umumnya tenaga kebersihan di Kabupaten Tabanan di berikan upah lebih rendahdari nilai upah normatif sebesar $\mathrm{Rp}$ 1.800.000/bulannya.Selisih pembayaran upah nyata bervariasi antara 48\%-56\%. Selisih nilai imbalan normatif terkecil ada pada upah mandor sebesar 56\% atau Rp 780.000 dan selisih nilai imbalan normatif terbesar ada pada tenaga sapu sebesar $48 \%$ atau Rp 930.000, yang mana resiko kerja paling tinggi tetapi mendapat bayaran upah yang paling rendah. Meskipun begitu mereka tidak keluar dari organisasi ini karena mereka merasa jika mereka keluar dari organisasi ini mereka tidak akan mendapatkan pekerjaan lain,disatu sisi Dinas Lingkungan Hidup Kabupaten Tabanan jugatidak memaksa pekerjanya untuk tetap bekerja diorganisasi tersebut sehingga tidak ada tekanan atau paksaan dari pihak manapun, namun para pekerja tetap mempertahankan pekerjaannya diorganisasi tersebut. Rasa tidak setujuini paling dominan pada pekerja dibagian motor gerobakdan dibagian cikar. Hal ini membuat para pekerja memiliki pekerjaan lain diluar organisasi untuk mendapat penghasilan tambahan, namun disisi lain pekerja merasa cukup setuju dengan pembayaran kompensasi yang tepat waktu.Hasil penelitian ini sesuai dengan penelitian sebelumnya yang dilakukan oleh Rizal et al. (2014) dan Milgo et al. (2014) dimana kompensasi berpengaruh signifikan terhadap komitmen organisasional. menemukan hasil kompensasi menunjukan pengaruh signifikan dengan komitmen karyawan.

Hasil pengujian hipotesis mengungkapkan bahwa pengaruh keselamatan dan kesehatan kerja tidak leboh besar dari kompensasi. Berdasarkan hasil analisis datamengungkapkan bahwa kebijakan keselamatan dan kesehatan kerja positif $(4,03)$. Walaupun K3 pada organisasi ini sudah baik karena organisasi menetapkan peraturan keselamatan kerja, memberikan pengarahan tentang pentingnya alat pelindung diri, kecelakaan selalu dilaporkan pada atasan, dan para pekerja mengetahui dengan baik prosedur bekerja dengan aman serta mematuhi peraturan keselamatan kerja maka organisasi harus tetap mempertahankan semua yang sudah diterapkan sampai sejauh ini. Masih ada peraturan yang belum ditetapkan oleh organisasi ini seperti pemberian jaminan asuransi kesehatan yang sangat penting bagi tenaga kerja. Temuan inimengungkapkan hasil yang serupa dengan yang di laporkan oleh Damayanthi \& Sintaasih (2016) dimana Keselamatan dan Kesehatan Kerja (K3) memiliki pengaruh positif pada komitmen organisasional.Upaya proaktif manajemen perusahaan untuk menciptakan program keselamatan dan kesehatan kerja yang baik dapat mendorong karyawan 
untuk terus mengabdi dan memiliki keterikatan secara emosional dengan perusahaan.

Hasil dari penelitian ini menujukkan bahwa kompensasi berpengaruh positif terhadap komitmen organisasional kemudian keselamatan dan kesehatan kerja juga berpengaruh positif terhadap komitmen organisasional.Beberapa implikasi dari hasil penelitian ini, yakni bahwa responden tidak setuju dengan gaji yang diberikan, seharusnya organisasi membuat sistem gaji yang lebih baik yang sesuai dengan PP No. 78 Tahun 2015 tentang pengupahan yang telah ditetapkan oleh pemerintah agar tenaga kerja tetap memiliki komitmen yang kuat dengan Dinas Lingkungan Hidup Kabupaten Tabanandan disesuikan juga dengan beban kerja yang ditanggung oleh tenaga kerja di lapangan serta tanggung jawab yang diberikan ke tenaga kerja agar para tenaga kerja tetap memiliki komitmen organisasional yang tinggi pada organisasi.Pentingnya dilakukan penyesuaian ulang pada upah yang diberikan merupakan salah satu cara agar tenaga kerja merasa puas bekerja diorganisasi ini.

Hasil penelitian ini juga mengemukakan bahwa penerapan keselamatan dan kesehatan kerja di Dinas Lingkungan Hidup Kabupaten Tabanan dalam keadaan baik hal tersebut sesuai dengan skor yang didapatkan pada penyataan yang diberikan, skor yang diperoleh sebanyak 3,87 yang artinya setuju. Walaupun keselamatan dan kesehatan kerja diorganisasi ini sudah dikatakan baik tetapi masih ada beberapa hal yang harus ditingkatkan lagi yakni salah satunya pengadaan jaminan asuransi kesehatan, hal ini sangatlah penting jika dilihat dari lingkungan kerja yang banyak resikonya.Seperti UU Tahun 1970 berisikan tentang keselamatan dan kesehatan kerja yang dimana memiliki beberapa elemen diantaranya mencegah dan mengurangi kecelakaan kerja serta pertolongan pada kecelakaan kerja.

Terdapat beberapa keterbatasan yang mempengaruhi kondisi dari penelitian yang dilakukan. Adapun beberapa keterbatasan dalam penelitian ini yaitu Kebanyakan responden yang tidak mengenyam pendidikan membuat proses didalam wawancara terbilang cukup lama karena peneliti harus mensederhanakan lagi kalimat pernyataan yang diberikan agar mudah dimengerti. Pengukuran kompensasi tidak meliputi tunjangan kecelakaan kerja. Disarankan pada penelitian berikutnya berkaitan dengan asuransi kesehatan jiwa atau kecelakaan kerja ditambahkan karena hal tersebut memiliki relevansi tinggi baik terhadap variabel kompensasi maupun variabel keselamatan dan kesehatan kerja sebagai mana yang diatur pada UU No. 13 Tahun 2003 yang berisikan tentang pengupahan dan perlingdungan tenaga kerja.

\section{SIMPULAN}

Berdasarkan hasil analisis penelitian dan hasil pembahasan pada bab sebelumnya maka simpulan dari penelitian ini adalah sebagai berikut: 1) Para tenaga kerja merasa kurang puas terhadap kompensasi yang diberikan, akan tetapi mereka tetap tinggal diorganisasi ini hal tersebut karenakan tidak adanya pilihan lain sehingga mereka tetap tinggal diorganisasi ini. 2) Jika dilihat dari segi peraturan perundang-undangan yang berlaku jelas organisasi ini telah melanggar 
peraturan perundang-undangan mengenai aturan di dalam penetapan UMK. 3) Penelitian ini dapat dijadikan acuan bagi kabupaten lain sehingga perlu dilakukan replikasi penelitian ini pada kabupaten lain untuk menilai konsistensi didalam pemberian kompensasi dan terkait dengan keselamatan dan kesehatan kerja. 4) Ada beberapa hal yang belum dipenuhi oleh organisasi salah satunya memberi jaminan kesehatan. Ini sangatlah penting dikarenakan lingkungan kerja mereka yang kotor dan dapat menimbulkan penyakit yang serius.

Saran yang dapat diberikan berdasarkan hasil analisis dan pembahasan adalah sebagai berikut : 1) Dinas Lingkungan Hidup Kabupaten Tabanan diharapkan dapat meningkatkan nominal kompensasi yang diberikan sehingga karyawan tidak perlu mengerjakan pekerjaan lain untuk mendapatkan penghasilan tambahan dan karyawan tidak tertarik untuk meninggalkan organisasi. 2) Masih ada beberapa hal-hal penting tentang $\mathrm{K} 3$ yang belum di terapkan semoga kedepannya bias di terapkan dengan lebih maksimal seperti pentingnya perlindungan tenaga kerja mendapatkan asuransi kesehatan dan kecelakaan kerja sebagaimana yang dinyatakan dalam UU No. 13 Tahun 2003. 3) Berkaitan dengan ini lakukan replikasi pada tenaga kerja dibidang kebersihan di kabupaten yang lainnya untuk menilai konsistensi kabupaten lain didalam pemberian kompensasi dan terkait dengan keselamatan dan kesehatan kerja. 4) Berkaitan dengan penelitian selanjutnya agar dapat menambahkan variabel asuransi dan keselamatan kerja pada model penelitian berikutnya karena variabel tersebut sangatlah relevan dengan variabel kompensasi dan keselamatan dan kesehatan kerja.

\section{REFERENSI}

Bhatti, K. . (2011). Influence Of Employee Compensationon Organizational Commitment And Job Satisfaction: A Case Study Of Educational Sector Of Pakistan. International Journal Of Business And Social Science, 2(8), 2532.

Budianto, F. (2014). Pengaruh Keselamatan Dan Kesehatan Kerja Terhadap Komitmen Organisasional Karyawan Pada Bagian Produksi PT. Sumber Kencana Di Bojonegoro. AGORA, 2(1), 1-20.

Damayanthi, A. A. S. S., \& Sintaasih, D. K. (2016). Pengaruh Keselamatan Dan Kesehatan Kerja Terhadap Komitmen Organisasional Dan Kinerja Karyawan. Forum Manajemen, 14(2), 1-12.

Darma, P. S., \& Supriyanto, A. S. (2017). The Effect Of Compensation On Satisfaction And Employees Performance. Management And Economic Journal, 1(1), 69-75.

Daulay, I. N., \& Ristiani, E. (2015). Pengaruh Program Kesehatan \& Keselamatan Kerja Dan Lingkungan Kerja Terhadap Kinerja Karyawan Bagian Produksi Pada Pt. Surya Bratasena Plantation Pelalawan. Jurnal Online Mahasiswa Fakultas Ekonomi Universitas Riau, 2(1), 1-17. 
Erfa, R. T. M., \& Kasmiruddin. (2014). Pelaksanaan Program Keselamatan Kesehatan Kerja (K3) Dalam Rangka Mengurangi Kecelakaan Karyawan (Kasus Bagian Teknik Dan Distribusi PT. PLN Ranting Bangkinang). Jurnal Online Mahasiswa, 1(1), 1-14.

Ghozali, I. 2016. Aplikasi Analisis Multivariate dengan Program IBM SPSS 23. Semarang: BPFE Universitas Diponegoro.

Hazra, K., Sengupta, P. P., \& Biswakarma, S. K. (2018). Compensation : Policies $\&$ Practices And Its Impact On Employee Commitment In The Hospitality Industry. International Journal Of Humanities And Social Science Invention (IJHSSI), 7(04), 42-53.

Junaedi, D., Swasto, B., \& Utami, H. . (2013). Pengaruh Gaya Kepemimpinan, Keselamatan Dan Kesehatan Kerja, Kepuasan Kerja Terhadap Komitmen Organisasional (Studi Pada Karyawan PG. Kebet Baru Malang). Jurnal Profit, 7(1), 127-136.

Kee, L. B., Ahmad, R. Bin, \& Abdullah, S. M. (2016). Relationship Between Financial Compensation And Organizational Commitment Among Malaysian Bank Workers. Asian Business Research, 1(1), 75-78.

Kerisna, I. G. M. A., \& Suana, I. W. (2017). Pengaruh Kepuasan Kerja Terhadap Komitmen Organisasional Dan Organizational Citizenship Behavior. EJurnal Manajemen Unud, 6(7), 3962-3990.

Milgo, A. C., Namusonge, G., Kanali, C., \& Makokha, E. N. (2014). Reward And Compensation As A Determinant Of Employee Commitment. A Survey Of Ktda Tea Factories In Kenya. European Journal Of Business And Management, 6(5), 117-125.

Munandar, M. R., Astuti, E. S., \& Hakam, M. S. (2014). Pengaruh Keselamatan, Kesehatan Kerja (K3) Dan Insentif Terhadap Motivasi Dan Kinerja Karyawan (Studi Pada Pekerja Bagian Produksi PT. Sekawan Karyatama Mandiri Sidoarjo). Jurnal Administrasi Bisnis (JAB), 9(1), 1-40.

Nawawi, M., Syarifuddin, A., Sehe, M., \& Ekawati, H. (2018). The Effect Compensation And Organization Culture On The Motivation And Commitment Organization Coal Company In East Kalimantan Province. International Journal Of Scientific And Technology Research, 7(9), 11-14.

Parashakti, R. D., Nashar, M., \& Usliawati, D. (2017). The Effect Of Compensation And Organization Commitment Towards Turnover Intention. Case Study In ILC (International Language Center) Jakarta. Advances In Intelligent Systems Research, 131(Icoi), 117-127. Https://Doi.Org/10.2991/Icoi-17.2017.19

Praveena, R., \& Monica, B. S. (2017). Study On Impact Of Employee Communication On Employee A Study On Impact Of Employee Communication On. IJARIIE, 3(5), 1174-1184. 
Riana, I. G., \& Wirasedana, I. W. P. (2016). The Effect Of Compensation On Organisational Commitment And Employee Performance With The Labour Union As The Moderating Variable. Scientific Journal Of PPI-UKM, 3(2), 83-88. Https://Doi.Org/10.21752/Sjppi-Ukm/Ses/A29082016

Rizal, M., Idrus., M. S., \& Djumahir, R. M. (2014). Effect Of Compensation On Motivation, Organizational Commitment And Employee Performance (Studiesat Local Revenue Management In Kendari City). International Journal Of Business And Management Invention, 3(2), 64-79.

Rizal, M., Idrus, M. S., Djumahir, \& Mintarti, R. (2014). Effect Of Compensation On Motivation, Organizational Commitment And Employee Performance (Studies At Local Revenue Management In Kendari City). International Journal Of Business And Management Invention, 3(2), 2319-8028. Https://Doi.Org/2319-8028

Salisu, J. B., Chinyio, E., \& Suresh, S. (2015). The Impact Of Compensation On The Job Satisfaction Of Public Sector Construction Workers Of Jigawa State Of Nigeria. The Business And Management Review, 6(4), 20.

Setiawan, I. P. I., \& Piartrini, P. S. (2018). Pengaruh Pemberdayaan Karyawan Dan Stres Kerja Terhadap Komitmen Organisasional Karyawan Departemen Housekeeping Pada Villa Ocean Blue Di Nusa Dua. E-Jurnal Manajemen Unud, 7(1), 1-20.

Smith, A., \& Sonesh, S. (2011). How Hazards And Safety Training Influence Learning And Performance. Journal Of Applied Psychology 2011 American Psychological Associatio, 96(1), 46-70. Https://Doi.Org/10.1037/A0021838,

Sopiah. (2013). The Effect Of Compensation Toward Job Satisfaction And Job Performance Of Outsourcing Employees Of Syariah Banks In Malang Indonesia. International Learning And Development, 3(2), 77-91.

Suartha, A. C., \& Sintaasih, D. K. (2015). Penerapan Program Keselamatan Dan Kesehatan Kerja Dan Kompensasi: Pengaruhnya Terhadap Kinerja Petugas Kebersihan Dinas Kebersihan Dan Pertamanan Kota Denpasar. E-Jurnal Manajemen Unud, 4(9), 2507-2526.

Tarigan, V. (2015). Empirical Study Relations Job Satisfaction, Organizational Commitment, And Turnover Intention. International Business \& Economic Research Journal, 5(2), 21-42.

Tarus, B. K. (2016). Compensation Strategies And Employee Commitment In Kenya: A Quantitative Analysis On Public Sector. International Journal Of Quantitative And Qualitative Research Methods, 4(1), 35-40. Https://Doi.Org/10.1109/Ciced.2018.8592188 
E-Jurnal Manajemen, Vol. 9, No. 4, 2020 : 1297-1317

Yusnita, N., \& Sari, I. P. (2014). Pengaruh Kompensasi Terhadap Kinerja Karyawan Pada PT. Tirta Investama (Danone AQUA). Jurnal Ilmiah Manajemen Dan Akuntansi Fakultas Ekonomi, 1(2), 23-27. 